\title{
4.1N suppresses hypoxia-induced epithelial-mesenchymal transition in epithelial ovarian cancer cells
}

\author{
LETIAN ZHANG $^{1}$, AJIN HU ${ }^{1}$, MENGRUI LI ${ }^{1}$, HONGQUAN ZHANG ${ }^{2}$, \\ CAIXIA REN ${ }^{2}$, XIULI AN ${ }^{3,4}$ and CONGRONG LIU ${ }^{5}$ \\ ${ }^{1}$ Department of Pathology, School of Basic Medical Sciences; ${ }^{2}$ Department of Histology and Embryology, \\ Peking University Health Science Center, Beijing 100191; ${ }^{3}$ College of Life Science, Zhengzhou University, \\ Zhengzhou, Henan 450051, P.R. China; ${ }^{4}$ Red Cell Physiology Laboratory, New York Blood Center, \\ New York, NY 10065, USA; ${ }^{5}$ Department of Pathology, School of Basic Medical Sciences, \\ Third Hospital, Peking University Health Science Center, Beijing 100191, P.R. China
}

Received January 18, 2015; Accepted October 29, 2015

DOI: $10.3892 / \mathrm{mmr} .2015 .4634$

\begin{abstract}
Protein 4.1N (4.1N) is a member of the protein 4.1 family and is essential for the regulation of cell adhesion, motility and signaling. Previous studies have suggested that $4.1 \mathrm{~N}$ may serve a tumor suppressor role. However, the molecular mechanisms remain unclear. In the current study, the role of $4.1 \mathrm{~N}$ in the downregulation of hypoxia-induced factor $1 \alpha(\mathrm{HIF}-1 \alpha)$ under hypoxic conditions and therefore the suppression of hypoxia induced epithelial-mesenchymal transition (EMT) was investigated. The data were obtained from overexpressed and knockdown 4.1N epithelial ovarian cancer (EOC) cell lines. It was identified that $4.1 \mathrm{~N}$ was capable of regulating the sub-cellular localization and expression levels of HIF-1 $\alpha$, by which $4.1 \mathrm{~N}$ served a dominant role in the suppression of hypoxia-induced EMT and associated genes. Collectively, the data of the current study identified $4.1 \mathrm{~N}$ as an inhibitor of hypoxia-induced tumor progression in EOC cells and highlighted its potential role in EOC therapy.
\end{abstract}

\section{Introduction}

Epithelial ovarian cancer (EOC) is a gynecological cancer associated with high mortality worldwide (1). In the USA, the number of newly diagnosed cases and the cases of EOC-associated mortality were 21,980 and 14,270, respectively, in 2014 (2). Although it has been previously demonstrated that a variety of non-specific symptoms prior to diagnosis occur in the majority of patients, early diagnosis remains a challenge (3). Furthermore, peritoneal dissemination, which

Correspondence to: Mrs. Congrong Liu, Department of Pathology, School of Basic Medical Sciences, Third Hospital, Peking University Health Science Center, 38 College Road, Haidian, Beijing 100191 , P.R. China

E-mail: congrong_liu@bjmu.edu.cn

Key words: epithelial ovarian cancer, 4.1N, EMT, hypoxia, HIF-1 $\alpha$ is induced by hypoxic stress resistance, contributes substantially to the mortality rate of patients with EOC (4-7). Thus, it is essential to understand the molecular mechanisms of hypoxia-induced EOC progression.

$4.1 \mathrm{~N}$, the protein product of the EPB $41 \mathrm{~L} 1$ gene, is a member of the protein 4.1 family (8). The members of the protein 4.1 family include 4.1R (9), 4.1B (10), 4.1G (11) and 4.1N (12). Protein 4.1 family members connect the actin cytoskeleton to various transmembrane proteins (12) and serve important roles in cell morphogenesis, membrane structure and cell adhesion (13). Recently, the roles of protein 4.1 family members in growth regulation and tumor development have become increasingly recognized, and a loss of $4.1 \mathrm{~B}$ and $4.1 \mathrm{R}$ expression has been reported in lung, breast, prostate, ovary and brain cancer, and meningioma (14-16). However, the role of $4.1 \mathrm{~N}$ in cancer remains to be fully elucidated. It was previously reported that defective expression of $4.1 \mathrm{~N}$ was correlated with tumor progression, aggressive behavior and chemotherapy resistance in EOC (17). Experiments on nude mice (unpublished data) have demonstrated that $4.1 \mathrm{~N}$ may significantly inhibit the ability of peritoneal dissemination of EOC cells.

Hypoxia contributes to enhanced invasiveness, angiogenesis and distant metastasis in various tumor types (18). Previous studies have indicated that hypoxia serves an important role in the initiation of peritoneal dissemination of EOC cells $(8,18,19)$. The most important regulator under low levels of oxygen is hypoxia-inducible factor-1 (HIF-1), which is comprised of the HIF- $1 \alpha$ and HIF- $1 \beta$ subunits (20). Hypoxic conditions activate HIF- $1 \alpha$ during numerous critical behaviors of cancer progression, including angiogenesis $(21,22)$, energy metabolism (23), resistance to radiation therapy and chemotherapy $(24,25)$ and epithelial-mesenchymal transition (EMT) (26-28). In cancer, EMT serves an important role in tumor progression and is marked by a loss of epithelial features, particularly loss of E-cadherin and an upregulation of mesenchymal properties (29-31). HIF-1 $\alpha$ is an important factor in controlling the expression of certain EMT regulators, including Snail, Twist and lysyl oxidase (LOX), all of which are involved in various EMT processes occurring during embryogenesis and tumorigenesis $(7,27,32,33)$. 
The current study hypothesized that $4.1 \mathrm{~N}$ may suppress hypoxia-induced EMT in EOC cells via regulating the expression levels and subcellular localization of HIF-1 $\alpha$.

\section{Materials and methods}

Cell culture. A2780 and SKOV-3 cells (American Type Culture Collection, Manassas, VA, USA) were cultured in Dulbecco's modified Eagle's medium (Gibco; Thermo Fisher Scientific, Inc., Waltham, MA, USA) and RPMI-1640 (Gibco; Thermo Fisher Scientific, Inc.), respectively with $10 \%$ fetal bovine serum (FBS; Yuanheng JInma Biotechnology Co. Ltd., Beijing, China). Cells were cultured with $2 \mathrm{mg} / \mathrm{ml} \mathrm{NaHCO}$ at $37^{\circ} \mathrm{C}$ in a humidified chamber with $5 \% \mathrm{CO}_{2}$. To mimic hypoxic conditions, cells were starved with $0.5 \%$ FBS and then were treated with $\mathrm{CoCl}_{2}$ (Aladdin Industrial, Inc., Shanghai, China) at $250 \mu \mathrm{mol}$ for different lengths of time. Cells were treated for a different length of time to induce HIF-1 $\alpha$ expression due to the diverse characteristics of A2780 (12 and $24 \mathrm{~h}$ ) and SKOV-3 (48 and $72 \mathrm{~h}$ ) cells.

Cell transfection and RNA interference. A2780 cells were transfected with pEGFP-4.1N [provided by Dr Xiuli An (Red Cell Physiology Laboratory, New York Blood Center, New York, NY, USA) with sequencing identification being performed in Gynecological Oncology Laboratory, Department of Pathology, Peking University, Beijing, China] or pEGFP-3C with Lipofectamine ${ }^{\circledR} 2000$ transfection reagent (Invitrogen; Thermo Fisher Scientific, Inc.) according to the manufacturer's instructions. Human 4.1 short hairpin RNA (shRNA) was obtained from Shanghai GenePharma Co. Ltd. (Shanghai, China). The target sites for $4.1 \mathrm{~N}$ shRNA were 5'-GCA ACATCACTCGAAATAA-3' (sh4.1N-1) and 5'-ACGGAAATCCGTTCTCTTT-3' (sh4.1N-2). For knocking down $4.1 \mathrm{~N}$, two independent experiments with the above two shRNAs were conducted and the efficiency of interference was confirmed. A scrambled shRNA 5'-TGT TCGCATTATCCGAACCAT-3' was used as a negative control. The cell line (SKOV-3) that endogenously expressed $4.1 \mathrm{~N}$ was transfected with different shRNA constructs to evaluate the effects on tumor cells. Subsequent to incubation at $37^{\circ} \mathrm{C}$ for $24 \mathrm{~h}, \mathrm{G} 418(800 \mu \mathrm{g} / \mathrm{ml}$; Invitrogen; Thermo Fisher Scientific, Inc.) was applied to stably screen and isolate the resistant colonies.

Cell viability assay. The cells were seeded (3,000 cells/well) into 96-well plates and were incubated at $37^{\circ} \mathrm{C}$ with $5 \%$ carbon dioxide in the presence of $\mathrm{CoCl}_{2}(200,250,300$ and $0 \mu \mathrm{mol}$ cell control) for different lengths of time. The negative control group underwent the same procedures, however the cells were not plated. At each end point, a batch of cells was stained with $20 \mu 1$ sterile 3-(4,5-dimethylthiazol-2-yl)-2,5diphenyltetrazolium bromide dye $(5 \mathrm{mg} / \mathrm{ml}$; Sigma-Aldrich, St. Louis, MO, USA) at $37^{\circ} \mathrm{C}$ for $4 \mathrm{~h}$. The culture medium was then removed and $150 \mu 1$ dimethyl sulfoxide (Sigma-Aldrich) was added and thoroughly mixed for $10 \mathrm{~min}$. The cell viability assay was applied to spectrometric absorbance at $490 \mathrm{~nm}$ and was measured using a microplate reader (Thermo Fisher Scientific, Inc.). The cell viability rate was calculated as (treatment group-negative control group)/(cell control group-negative control group). Each group contained six wells and the experiments were performed in triplicate.

Western blotting analysis. Cells were lysed in radioimmunoprecipitation assay lysis buffer supplemented with a protease inhibitor cocktail (Applygen Technologies, Inc., Beijing, China). The cells were then centrifuged at $10,000 \mathrm{xg}$ for $10 \mathrm{~min}$ at $4^{\circ} \mathrm{C}$. The supernatant was collected, protein $(30 \mu \mathrm{g})$ was denatured in sodium dodecyl sulfate (SDS) sample buffer (Applygen Technologies, Inc.) at $100^{\circ} \mathrm{C}$ for $5 \mathrm{~min}$ and separated by electrophoresis on a $10 \%$ SDS-polyacrylamide gel electrophoresis (Applygen Technologies, Inc.), then transferred to a nitrocellulose membrane (Applygen Technologies, Inc.). The membranes were blocked in Tris-buffered saline with Tween-20 (TBST) with 5\% non-fat milk for $1 \mathrm{~h}$ at $37^{\circ} \mathrm{C}$, then were incubated with the following primary antibodies: rabbit monoclonal E-cadherin (cat. no. 1702-1; 1:2,000) and rabbit polyclonal N-cadherin (cat. no. 21474; 1:500, purchased from Epitomics, Inc. (Burlingame, CA, USA), rabbit polyclonal HIF-1 $\alpha$ (cat. no. 3716; 1:1,000) from Cell Signaling Technology, Inc. (Danvers, MA, USA) and rabbit anti-4.1N (donated by Dr Xiuli An; 1:500) in blocking buffer (Applygen Technologies, Inc.) overnight at $4^{\circ} \mathrm{C}$. The membranes were washed three times in TBST and incubated with horseradish peroxidase-conjugated goat anti-rabbit antibody (cat. no. ZB-2301; 1:2,000) or anti-mouse (cat. no. ZB-2305; 1:2,000) antibodies (Beijing Zhongshan Golden Bridge Biotechnology Co., Ltd., Beijing, China) for $1 \mathrm{~h}$ at room temperature and then visualized by enhanced chemiluminescence (ECL) using a SuperEnhanced Chemiluminescence detection kit (Applygen Technologies, Inc.). The Gel Doc ${ }^{\mathrm{TM}}$ XR+ imaging system (Bio-Rad Laboratories, Inc., Hercules, CA, USA) was used for capturing the images.

Immunofluorescence. Cells grown on glass cover-slips were fixed with $4 \%$ paraformaldehyde for $10 \mathrm{~min}$ at room temperature. Subsequent to washing in phosphate-buffered saline (PBS; GE Healthcare Life Sciences, Chalfont, UK), the cells were incubated with the blocking reagent $[1 \%$ horse serum albumin (Gibco, Thermo Fisher Scientific, Inc.) in PBS] for 15 min. Cells were incubated with rabbit anti-HIF-1 $\alpha$ (cat. no. ZA-0552; 1:1,000; Beijing Zhongshan Golden Bridge Biotechnology Co., Ltd.) at $4^{\circ} \mathrm{C}$ overnight. The primary antibody was omitted for the negative control slides. Subsequent to washing, samples were incubated with Alexa Fluor 594-conjugated affinipure goat anti-rabbit IgG (Beijing Zhongshan Golden Bridge Biotechnology Co., Ltd.) for $1 \mathrm{~h}$ at $37^{\circ} \mathrm{C}$. Subsequent to staining with 6-diamino-2-phenylindole (Cell Signaling Technology, Inc.), the cells were examined under a microscope (U-TV0.5XC-3; Olympus, Tokyo, Japan).

Reverse transcription-quantitative polymerase chain reaction (RT-qPCR). Total RNA was extracted using TRIzol reagent (Invitrogen; Thermo Fisher Scientific, Inc.). cDNA was synthesized using the FastQuant RT kit [Tiangen Biotech (Beijing) Co., Ltd., Beijing, China]. cDNA (10 ng) was then used for the RT-qPCR reaction using SuperReal PreMix Plus [Tiangen Biotech (Beijing) Co., Ltd.]. RT-qPCR was performed using an iQ5 Real-Time PCR Detection System (Bio-Rad Laboratories, Inc.). The results were 
A
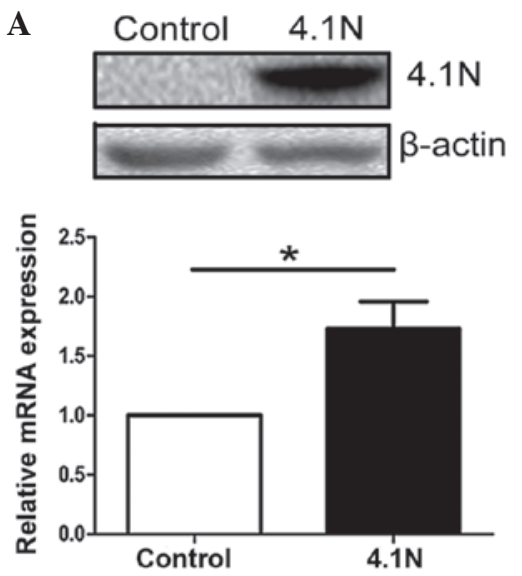

C

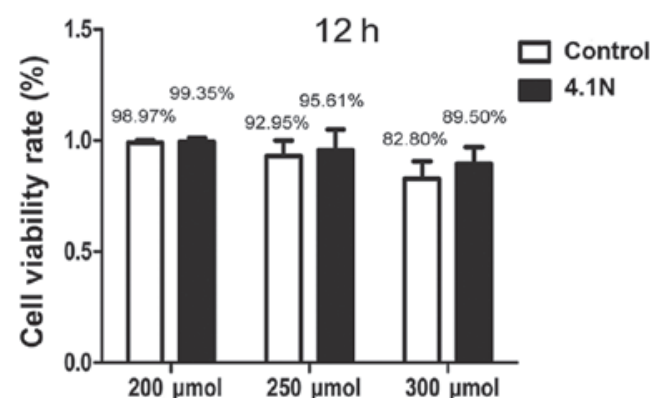

D

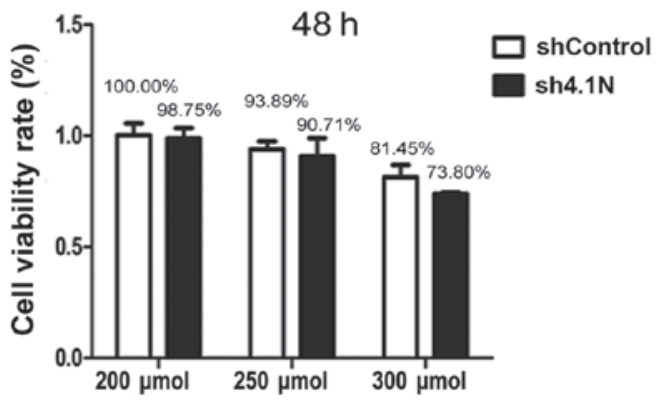

B
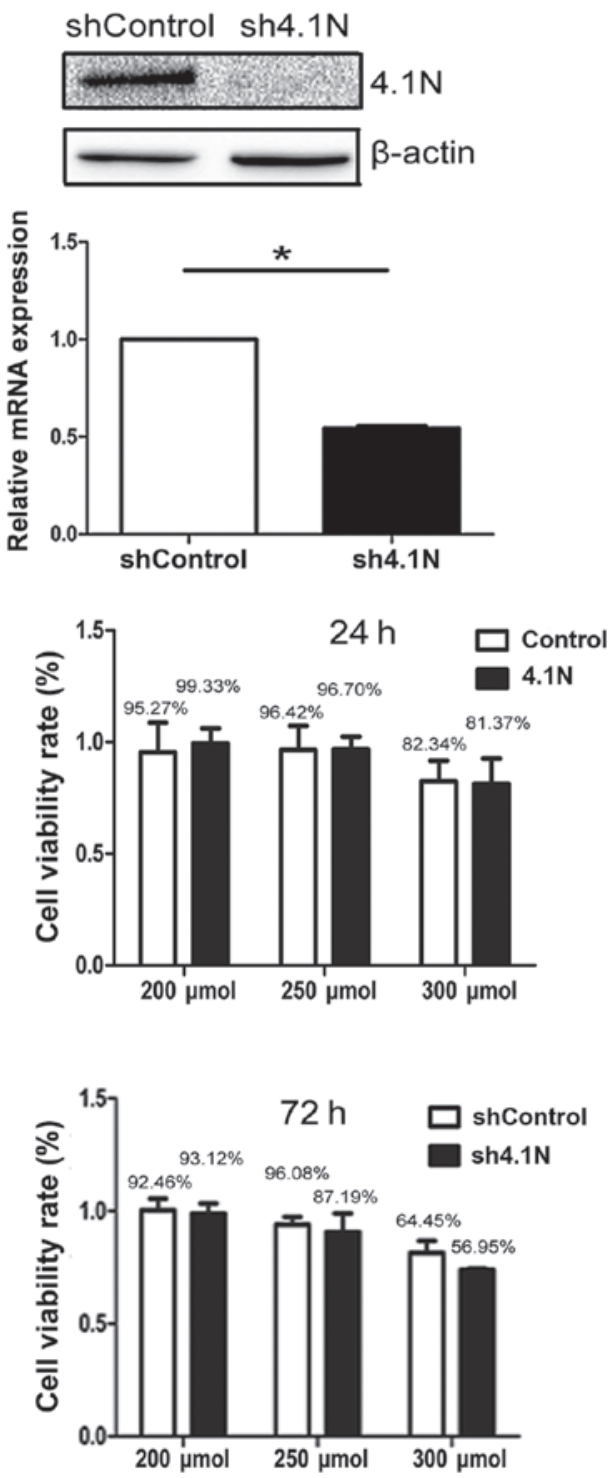

Figure 1. Overexpression of $4.1 \mathrm{~N}$ in A2780 cells, knockdown of $4.1 \mathrm{~N}$ in SKOV-3 cells and cell viability assay. (A) A2780 cells were transfected with the empty vector or $4.1 \mathrm{~N}$, then were subjected to western blotting and RT-qPCR analysis. (B) Knockdown of 4.1N using shRNA (sh4.1N) was performed in SKOV-3 cells. Scrambled shRNA (shControl) was used as the negative control. Western blotting and RT-qPCR analysis for the expression levels of 4.1N was conducted. (C and D) Cell viability assay of A2780 and SKOV-3 cells with 12 and 24 h treatment with CoCl $\mathrm{Ct}_{2} 200,250$ and $300 \mu$ mol and with controls for A 2780 cells and 48 and $72 \mathrm{~h}$ for SKOV-3 cells. Values are presented as the mean \pm standard deviation of triplicate measurements. ${ }^{*}<<0.05$. RT-qPCR, reverse transcription-quantitative polymerase chain reaction; shRNA, short hairpin RNA.

calculated by the $2^{-(\Delta \Delta \mathrm{Ct})}$ method. The primer sequences were as follows: $4.1 \mathrm{~N}$, forward 5'-AGGAAACCACGCCGA GACACAA-3' and reverse 5'-GGTGGATGAGTTTGCTGT TGGG-3'; Twist, forward 5'-GACAGTGATTCCCAGACG G-3' and reverse 5'-GTCCATAGTGATGCCTTTCCT-3'; Snail, forward 5'-TCGGAAGCCTAACTACAGCG-3' and reverse 5'-GATGAGCATTGGCAGCGAG-3'; HIF-1 $\alpha$, forward 5'-CTGAGGTTGGTTACTGTTGGTATC-3' and reverse 5'-AGTGTACCCTAACTAGCCGAGGAA-3'; LOX, forward 5'-ATGGTGCTGCTCAGATTTCC-3' and reverse 5'-TGACAACTGTGCCATTCCCA-3'. The cycling conditions were $95^{\circ} \mathrm{C}$ for $15 \mathrm{~min}$, followed by 40 cycles at $95^{\circ} \mathrm{C}$ for $10 \mathrm{sec}, 55^{\circ} \mathrm{C}$ for $20 \mathrm{sec}$ and $72^{\circ} \mathrm{C}$ for $30 \mathrm{sec}$.

Statistical analysis. All values are presented as the mean \pm standard deviation and are representative of an average of a minimum of three independent experiments. Student's t-test or analysis of variance for unpaired data was used to compare the mean values using GraphPad Prism software, version 5 (GraphPad Software, Inc., La Jolla, CA, USA). $\mathrm{P}<0.05$ was considered to indicate a statistically significant difference.

\section{Results}

4.1N inhibits expression and nuclear accumulation of $H I F-1 \alpha$ under hypoxia. A previous study indicated that $4.1 \mathrm{~N}$ protein was absent in A2780 and present in SKOV-3 cells (17). Overexpression of $4.1 \mathrm{~N}$ in $\mathrm{A} 2780$ and knockdown of $4.1 \mathrm{~N}$ in SKOV-3 cells was confirmed by western blotting and RT-qPCR (Fig. 1A and B), respectively. Subsequently, the role of $4.1 \mathrm{~N}$ in the regulation of HIF-1 $\alpha$ expression was investigated under hypoxia. A cell viability assay was conducted in order to confirm the amount of $\mathrm{CoCl}_{2}$ that could be tolerated by cells. 
A

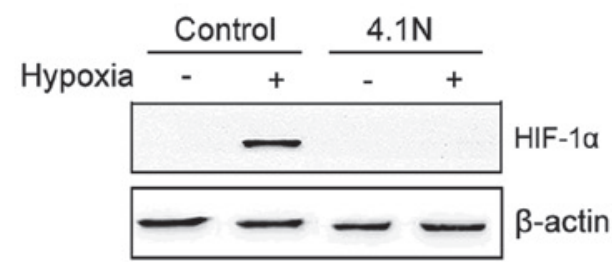

B

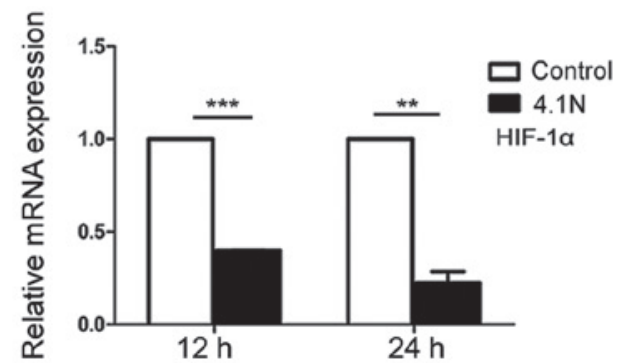

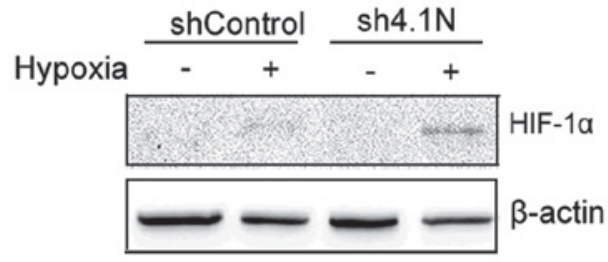

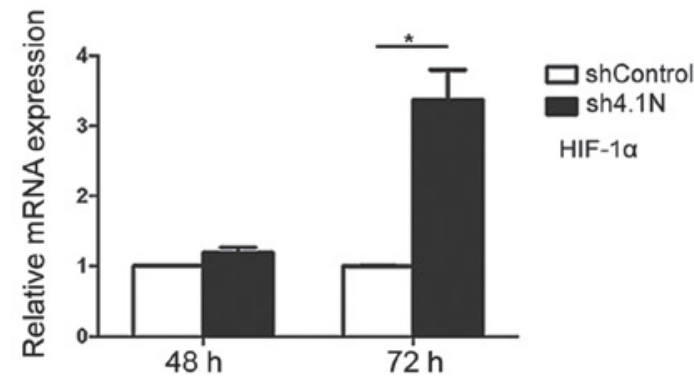

C

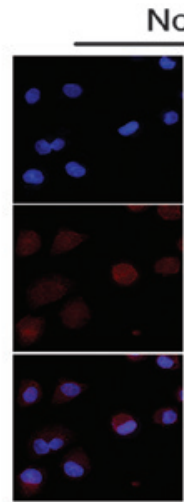

Control
Normal

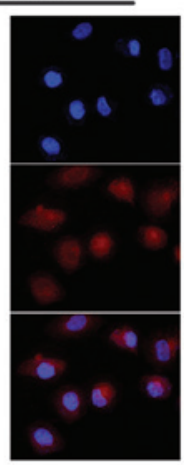

$4.1 \mathrm{~N}$

D

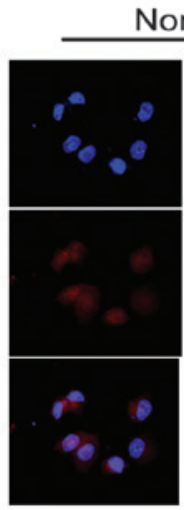

shControl
Normal

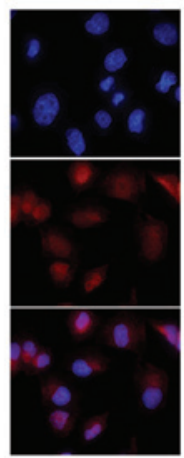

$\operatorname{sh} 4.1 \mathrm{~N}$

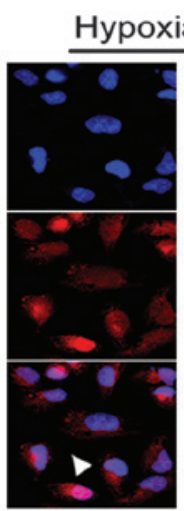

Control

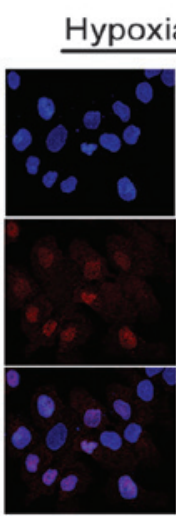

shControl

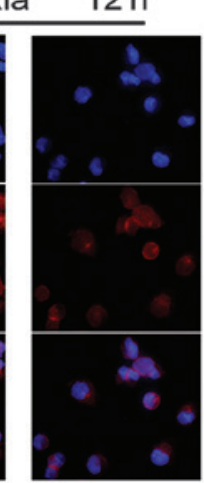

$4.1 \mathrm{~N}$

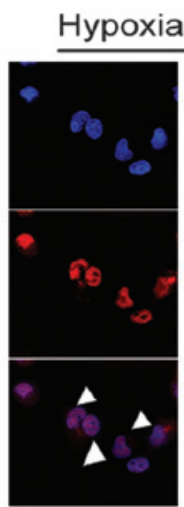

Control
$24 \mathrm{~h}$

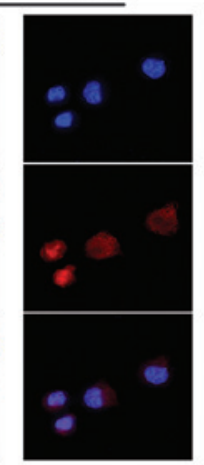

$4.1 \mathrm{~N}$
DAPI

HIF-1a

Merge

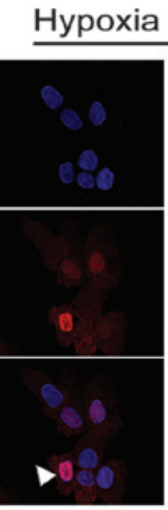

shControl
$72 \mathrm{~h}$
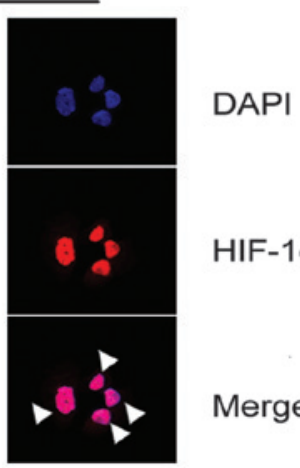

sh $4.1 \mathrm{~N}$

Figure 2. 4.1N inhibits the expression and nuclear accumulation of HIF-1 $\alpha$ under hypoxic conditions. (A) Western blot analysis of HIF-1 $\alpha$ in A2780 (control and $4.1 \mathrm{~N}$ ) cells and SKOV-3 (shControl and sh4.1N) cells following 24 and $72 \mathrm{~h}$ of hypoxia, respectively. (B) Under hypoxic conditions, A2780 (control and $4.1 \mathrm{~N}$ ) cells were cultured for 12 and $24 \mathrm{~h}$, while SKOV-3 (shControl and sh4.1N) cells were cultured for 48 and $72 \mathrm{~h}$. HIF-1 $\alpha$ mRNA levels were analyzed by reverse transcription-quantitative polymerase chain reaction. (C) A2780 cells (4.1N and control) and (D) SKOV-3 cells (shControl and sh4.1N) were cultured under normoxic and hypoxic conditions. Immunofluorescence analysis was performed at (C) 12 and $24 \mathrm{~h}$ subsequent to hypoxic induction for A2780 cells and (D) following 48 and $72 \mathrm{~h}$ hypoxia for SKOV-3 cells. Arrows indicate co-localization of HIF-1 $\alpha$ and 6-diamino-2-phenylindole. Values are presented as the mean \pm standard deviation of triplicate measurements. ${ }^{* * * *} \mathrm{P}<0.001,{ }^{* *} \mathrm{P}<0.005,{ }^{*} \mathrm{P}<0.05$. HIF-1 $\alpha$, hypoxia-inducible factor $1 \alpha$; sh, short hairpin.

In A2780 cells, the cell viability rate was greater than $90 \%$ when treated with $\mathrm{CoCl}_{2}$ at 200 and $250 \mu \mathrm{mol}$, however was reduced to less than $90 \%$ at $300 \mu$ mol. In SKOV-3 cells, due to the longer treatment duration ( 48 and $72 \mathrm{~h}$ ), the cell viability rate with $\mathrm{CoCl}_{2}$ at 200 and $250 \mu \mathrm{mol}$ was lower than that of A2780 cells, however remained greater than $85 \%$. However, with treatment with $300 \mu \mathrm{mol}$ for 48 and $72 \mathrm{~h}$, viability was reduced to approximately $60 \%$ (Fig. $1 \mathrm{C}$ and D). In western blot analysis, proteins were collected following 24 and $72 \mathrm{~h}$ hypoxia treatment for A2780 cells and SKOV-3 cells, respectively. Under normoxic conditions, the expression levels of HIF- $1 \alpha$ were significantly reduced in the presence of $4.1 \mathrm{~N}$. By contrast, the amount of HIF- $1 \alpha$ protein was markedly increased with the absence of $4.1 \mathrm{~N}$ (Fig. 2A). RT-qPCR results are presented in Fig. 2B. HIF-1 $\alpha$ mRNA expression was significantly downregulated in the presence of $4.1 \mathrm{~N}$; 

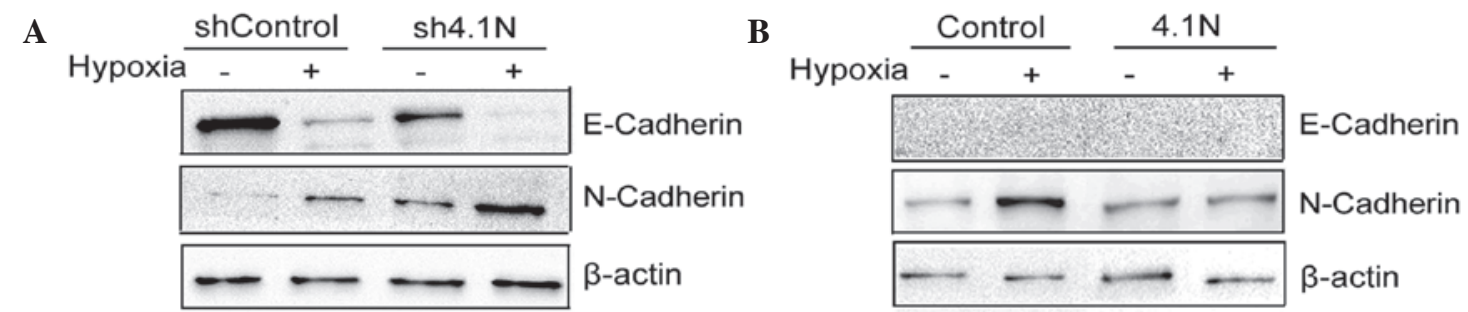

$\mathbf{C}$
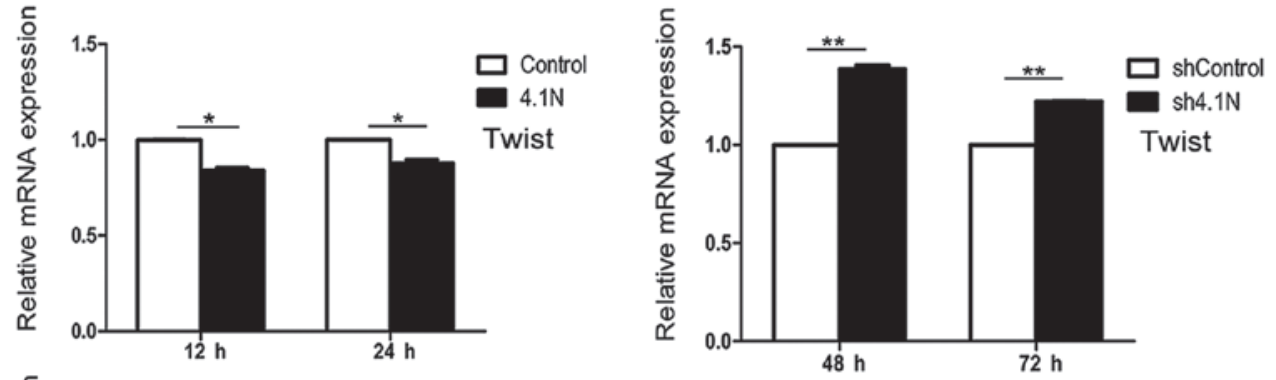

D
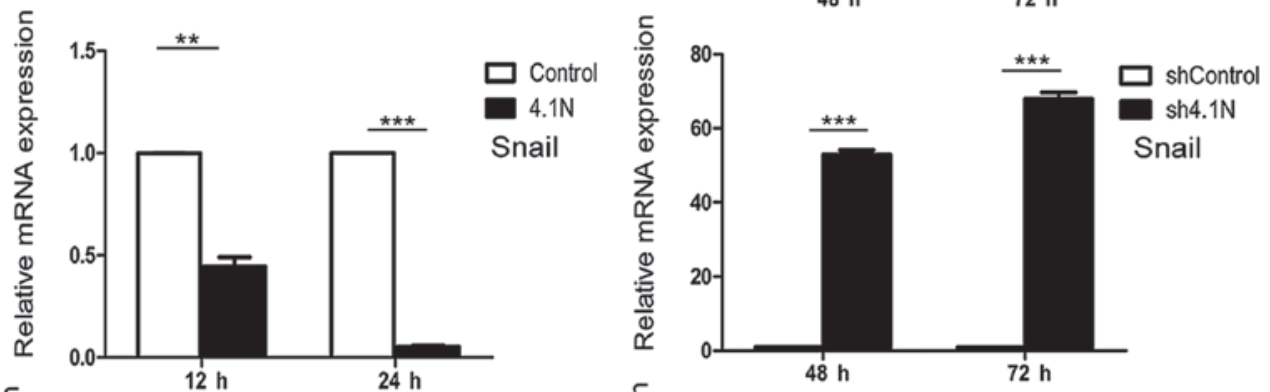

$\mathbf{E}$
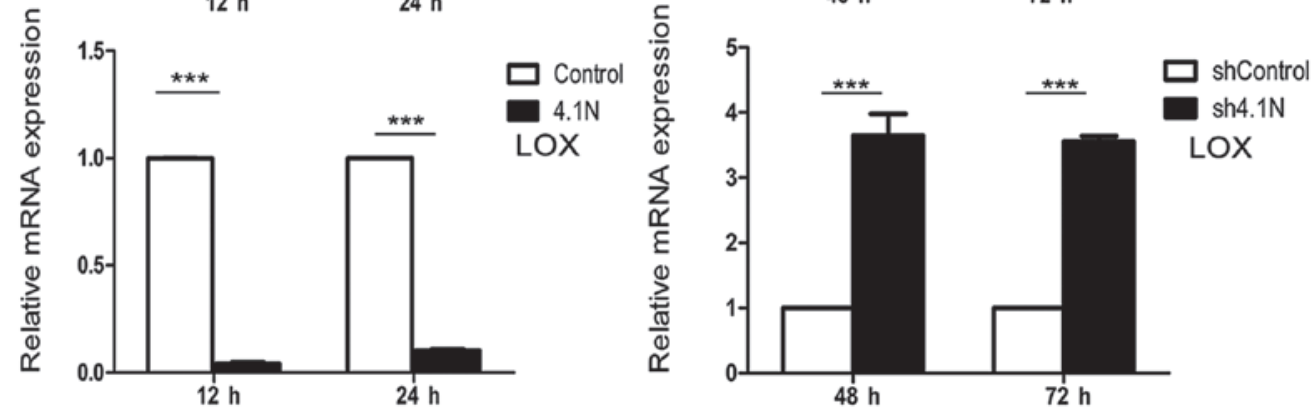

Figure 3. 4.1N affects the expression of E-cadherin and N-cadherin under hypoxia and inhibits the expression of genes that regulate epithelial-mesenchymal transition. Expression of E-cadherin and N-cadherin in (A) SKOV-3 (shControl and sh4.1N) cells subsequent to $72 \mathrm{~h}$ of hypoxia and (B) A2780 (control and $4.1 \mathrm{~N}$ ) cells following $24 \mathrm{~h}$ of hypoxia were analyzed by western blotting. (C-E) Under hypoxic conditions, A2780 (control and 4.1N) cells were cultured for 12 and $24 \mathrm{~h}$ while SKOV-3 (shControl and sh4.1N) cells were cultured for 48 and $72 \mathrm{~h}$. Relative mRNA levels of (C) Twist, (D) Snail and (E) LOX were analyzed by reverse transcription-quantitative polymerase chain reaction. Values are presented as the mean \pm standard deviation of triplicate measurements. ${ }^{* * *} \mathrm{P}<0.001,{ }^{* *} \mathrm{P}<0.005,{ }^{*} \mathrm{P}<0.05$. sh, short hairpin.

whereas, the stress-response of $4.1 \mathrm{~N}$-knockdown cells to hypoxia was significantly increased at $72 \mathrm{~h}$ compared with the control. Immunofluorescence staining was then conducted in order to confirm the alterations in HIF-1 $\alpha$ subcellular localization under hypoxia. Nuclear accumulation of HIF-1 $\alpha$ in 4.1N-overexpressing A2780 cells was observed to be markedly reduced compared with that of control cells under hypoxia, particularly following $24 \mathrm{~h}$ of hypoxia (Fig. 2C). In SKOV-3 cells, the absence of $4.1 \mathrm{~N}$ led to clear nuclear localization of HIF-1 $\alpha$ at 48 and $72 \mathrm{~h}$ compared with the controls (Fig. 2D). These results suggest that $4.1 \mathrm{~N}$ may suppress the expression and nuclear localization of HIF-1 $\alpha$ under hypoxic conditions.

$4.1 N$ inhibits hypoxia-induced EMT. Loss expression of epithelial markers such as E-cadherin and increases in expression of mesenchymal markers such as $\mathrm{N}$-cadherin are typical events of epithelial cells undergoing EMT. It was identified

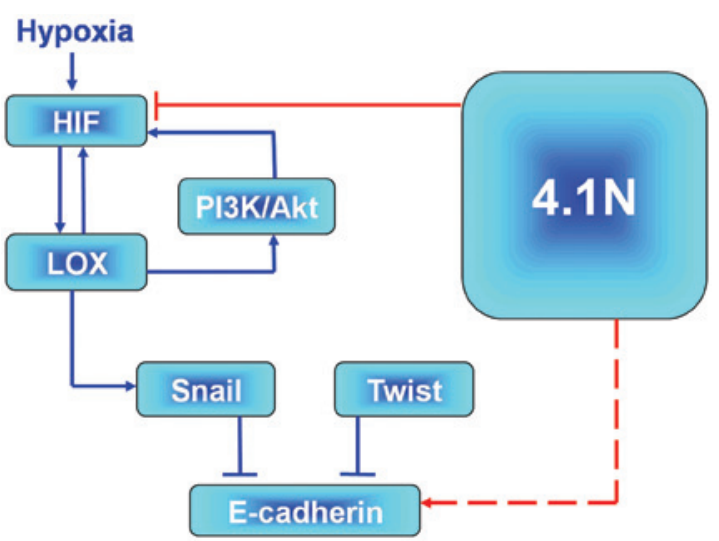

Figure 4. Proposed model for how 4.1N regulates hypoxia-induced epithelial-mesenchymal transition. 4.1N may inhibit HIF and upregulate E-cadherin via the HIF-LOX-Snail-E-cadherin cascade. $4.1 \mathrm{~N}$ may also suppress HIF or directly interact with E-cadherin. HIF, hypoxia-inducible factor; PI3K, phosphoinositide 3-kinase; Akt, protein kinase B; LOX, lysyl oxidase. 
that with the absence of $4.1 \mathrm{~N}$, the protein levels of E-cadherin were markedly reduced and the protein levels of $\mathrm{N}$-cadherin were upregulated under normoxic and hypoxic conditions, particularly with those with hypoxia (Fig. 3A). When $4.1 \mathrm{~N}$ was overexpressed, $\mathrm{N}$-cadherin expression was markedly reduced under conditions of hypoxia (Fig. 3B). However, due to the lack of endogenous expression of E-cadherin in A2780 cells, the effect of hypoxia on E-cadherin of A2780 cells in the 4.1N and control groups was not detected.

4.1N suppresses the expression of positive EMT regulators. Hypoxia, an important tumor micro-environmental factor, induces the expression of numerous EMT regulators, including Snail, Twist and LOX $(7,33,34)$. Thus, RT-qPCR was used to observe the transcriptional mRNA levels of Snail, Twist and LOX. Fig. 3C-E indicate that overexpression of $4.1 \mathrm{~N}$ may significantly inhibit the mRNA expression levels of the three measured EMT regulators under hypoxic stress, while their mRNA expression levels were significantly increased in the EOC cells in the absence of $4.1 \mathrm{~N}$ under hypoxia.

\section{Discussion}

The protein 4.1 family has been observed to serve an important role in the regulation of growth and tumor progression (35). A previous study indicated that $4.1 \mathrm{~N}$ was a potential tumor suppressor in EOC (17). Previous studies have indicated that peritoneal dissemination, in which EMT has been reported to be critical, is one of the key mechanisms in EOC progression $(4,6)$. Furthermore, the resistance to hypoxic-stress is essential for the induction of EMT and peritoneal dissemination (7,36). In the current study, it was demonstrated for the first time, to the best of our knowledge, that $4.1 \mathrm{~N}$ may inhibit hypoxia-induced EMT of EOC cells at least partly via the regulation of HIF-1 $\alpha$.

Previous studies have indicated that the increased expression and activation of HIF are closely associated with cancer progression and poor prognosis of patients (37-39). HIF-1 $\alpha$ has been previously reported to be correlated with the migration and invasion of EOC cells and has been demonstrated to be an important prognostic marker of patients with EOC (40-42). The results of the current study indicated that $4.1 \mathrm{~N}$ may inhibit the nuclear accumulation of HIF-1 $\alpha$ and suppress its expression.

Hypoxia-induced HIF activation is associated with a concomitant loss of E-cadherin (43), one crucial feature of EMT resulting in cancer metastasis and drug resistance. Imai et al (7) reported that immunolocalization of nuclear HIF-1 $\alpha$ was correlated with the loss of E-cadherin in EOC cells. In the current study, the results indicate that absence of $4.1 \mathrm{~N}$ may aggravate hypoxia-induced E-cadherin loss. It was observed that even under normoxic conditions, E-cadherin was additionally downregulated due to knockdown of $4.1 \mathrm{~N}$, which implied the potential interaction of $4.1 \mathrm{~N}$ and E-cadherin. Additionally, the upregulation of hypoxia-induced $\mathrm{N}$-cadherin expression was inhibited by $4.1 \mathrm{~N}$, which further suggested the role of $4.1 \mathrm{~N}$ in impeding hypoxia-induced EMT. The data of the current study appears to be in support of an E/N-cadherin switch during EMT (44).

Several transcriptional factors have been demonstrated to be involved in EMT during tumor development. In the current study, Snail, Twist and LOX (18) were investigated, which are important molecules interacting with HIF-1 $\alpha$ under hypoxic conditions (40). Snail and Twist have been demonstrated to induce EMT by repressing E-cadherin expression $(45,46)$ through hypoxia signaling and the classical phosphoinositide 3-kinase (PI3K)/protein kinase B (Akt) pathways $(31,47,48)$. In addition, the LOX family has multiple roles in tumor progression including altering extracellular matrix components (49) and regulating Snail (50). In EOC samples, LOX has been observed to be significantly associated with advanced clinical stages and metastasis (40). In the current study, a negative regulation of Twist, Snail and LOX by $4.1 \mathrm{~N}$ further suggested a role of $4.1 \mathrm{~N}$ in suppressing hypoxia-induced EMT.

According to the present data, an outline of the molecular pathway, which $4.1 \mathrm{~N}$ is involved in during the hypoxia-induced EOC progression can be provided. On one hand, the promising hypoxia signalling pathway, HIF-LOX-Snail-E-cadherin (15) may assist in explaining the mechanisms by which $4.1 \mathrm{~N}$ suppresses hypoxia-induced EMT. It was demonstrated that $4.1 \mathrm{~N}$ regulated $\mathrm{HIF}$, leading to the low expression of LOX and Snail and upregulation of E-cadherin. By contrast, it is also possible that $4.1 \mathrm{~N}$ may affect the hypoxia-induced expression of LOX via association with PI3K. LOX-HIF-1 $\alpha$ mutual regulation activated the AKT pathway in epithelial EOC (38) and it was previously reported that LOX activated the PI3K/Akt signaling pathway to upregulate HIF-1 $\alpha$ protein synthesis (49). In addition, the association of $4.1 \mathrm{~N}$ and PI3K was previoulsy demonstrated. Firstly, $4.1 \mathrm{~N}$ was demonstrated to regulate PI3K activity via interactions with the PI3K (50). Secondly, our previous proteomic analysis indicated that $4.1 \mathrm{~N}$ may upregulate the expression of inositol polyphosphate 5-phosphatase, an enzyme associated with PI3K. Therefore, $4.1 \mathrm{~N}$ may deregulate the activity of PI3K and subsequently inhibit the expression of HIF-1 $\alpha$ expression and Akt activity. LOX-HIF- $1 \alpha$ mutual regulation was demonstrated to activate the Akt pathway in epithelial EOC cells (40). In addition, Pez et al (51) reported that LOX was able to activate the PI3K/Akt signaling pathway to upregulate HIF-1 $\alpha$ protein synthesis and Ye et al (52) reported that $4.1 \mathrm{~N}$ regulated $\mathrm{PI} 3 \mathrm{~K}$ activity via interactions with the PI3K enhancer. In addition, proteome analysis (Zhang et al, unpublished data) indicated that $4.1 \mathrm{~N}$ may upregulate the expression of inositol polyphosphate 5-phosphatase, an enzyme associated with PI3K. It is notable that inositol polyphosphate 5-phosphatases may lead to apoptotic cell death (53), and share a potential role in tumor progression. Combining these two hypotheses, the predictive model presented in Fig. 4 is proposed. However, further studies are required to clarify the specific signaling networks.

In summary, the results of the present study indicate that $4.1 \mathrm{~N}$ is an important regulator for hypoxia-induced EOC progression. $4.1 \mathrm{~N}$ may be a potential tumor suppressor and a therapeutic target for patients with EOC.

\section{Acknowledgements}

The current study was supported by the National Natural Science Foundation of China (grant no. 81472430).

\section{References}

1. Hess LM and Stehman FB: State of the science in ovarian cancer quality of life research: A systematic review. Int J Gynecol Cancer 22: 1273-1280, 2012. 
2. Siegel R, Ma J, Zou Z and Jemal A: Cancer statistics, 2014. CA Cancer J Clin 64: 9-29, 2014.

3. Rooth C: Ovarian cancer: Risk factors, treatment and management. Br J Nurs 22 (Suppl): S23-S30, 2013.

4. Hua KT, Wang MY, Chen MW, Wei LH, Chen CK, Ko CH, Jeng YM, Sung PL, Jan YH, Hsiao M, et al: The H3K9 methyltransferase G9a is a marker of aggressive ovarian cancer that promotes peritoneal metastasis. Mol Cancer 13: 189, 2014.

5. Naora H and Montell DJ: Ovarian cancer metastasis: Integrating insights from disparate model organisms. Nat Rev Cancer 5: 355-366, 2005

6. Auersperg N, Wong AS, Choi KC, Kang SK and Leung PC: Ovarian surface epithelium: Biology, endocrinology and pathology. Endocr Rev 22: 255-288, 2001.

7. Imai T, Horiuchi A, Wang C, Oka K, Ohira S, Nikaido T and Konishi I: Hypoxia attenuates the expression of E-cadherin via up-regulation of SNAIL in ovarian carcinoma cells. Am J Pathol 163: 1437-1447, 2003.

8. Peters LL, Weier HU, Walensky LD, Snyder SH, Parra M, Mohandas N and Conboy JG: Four paralogous protein 4.1 genes map to distinct chromosomes in mouse and human. Genomics 54 348-350, 1998.

9. Conboy J, Kan YW, Shohet SB and Mohandas N: Molecular cloning of protein 4.1, a major structural element of the human erythrocyte membrane skeleton. Proc Natl Acad Sci USA 83: 9512-9516, 1986

10. Parra M, Gascard P, Walensky LD, Gimm JA, Blackshaw S, Chan N, Takakuwa Y, Berger T, Lee G, Chasis JA, et al: Molecular and functional characterization of protein $4.1 \mathrm{~B}$, a novel member of the protein 4.1 family with high level, focal expression in brain. J Biol Chem 275: 3247-3255, 2000.

11. Walensky LD, Blackshaw S, Liao D, Watkins CC, Weier HU, Parra M, Huganir RL, Conboy JG, Mohandas N and Snyder SH: A novel neuron-enriched homolog of the erythrocyte membrane cytoskeletal protein 4.1. J Neurosci 19: 6457-6467, 1999.

12. Wang H, Liu C, Debnath G, Baines AJ, Conboy JG, Mohandas N and An X: Comprehensive characterization of expression patterns of protein 4.1 family members in mouse adrenal gland: Implications for functions. Histochem Cell Biol 134: 411-420, 2010.

13. Sun CX, Robb VA and Gutmann DH: Protein 4.1 tumor suppressors: Getting a FERM grip on growth regulation. J Cell Sci 115: 3991-4000, 2002.

14. Dafou D, Grun B, Sinclair J, Lawrenson K, Benjamin EC, Hogdall E, Kruger-Kjaer S, Christensen L, Sowter HM, Al-Attar A, et al: Microcell-mediated chromosome transfer identifies EPB41L3 as a functional suppressor of epithelial ovarian cancers. Neoplasia 12: 579-589, 2010

15. Wong SY, Haack H, Kissil JL, Barry M, Bronson RT, Shen SS, Whittaker CA, Crowley D and Hynes RO: Protein 4.1B suppresses prostate cancer progression and metastasis. Proc Natl Acad Sci U S A 104: 12784-12789, 2007.

16. Robb VA, Li W, Gascard P, Perry A, Mohandas N and Gutmann DH: Identification of a third protein 4.1 tumor suppressor, protein $4.1 \mathrm{R}$, in meningioma pathogenesis. Neurobiol Dis 13: 191-202, 2003

17. Xi C, Ren C, Hu A, Lin J, Yao Q, Wang Y, Gao Z, An X and Liu C: Defective expression of protein $4.1 \mathrm{~N}$ is correlated to tumor progression, aggressive behaviors and chemotherapy resistance in epithelial ovarian cancer. Gynecol Oncol 131: 764-771, 2013

18. Pouysségur J, Dayan F and Mazure NM: Hypoxia signalling in cancer and approaches to enforce tumour regression. Nature 441: 437-443, 2006

19. Nakayama K, Kanzaki A, Hata K, Katabuchi H, Okamura H, Miyazaki K, Fukumoto M and Takebayashi Y: Hypoxia-inducible factor 1 alpha (HIF-1 alpha) gene expression in human ovarian carcinoma. Cancer Lett 176: 215-223, 2002.

20. Semenza GL: Oxygen sensing, homeostasis and disease. N Eng J Med 365: 537-547, 2011

21. Liao D and Johnson RS: Hypoxia: A key regulator of angiogenesis in cancer. Cancer Metastasis Rev 26: 281-290, 2007.

22. Lee K, Zhang H, Qian DZ, Rey S, Liu JO and Semenza GL: Acriflavine inhibits HIF-1 dimerization, tumor growth and vascularization. Proc Natl Acad Sci U S A 106: 17910-17915, 2009.

23. Luo W, Hu H, Chang R, Zhong J, Knabel M, O'Meally R, Cole RN, Pandey A and Semenza GL: Pyruvate kinase M2 is a PHD3-stimulated coactivator for hypoxia-inducible factor 1 . Cell 145: 732-744, 2011
24. Moeller BJ, Richardson RA and Dewhirst MW: Hypoxia and radiotherapy: Opportunities for improved outcomes in cancer treatment. Cancer Metastasis Rev 26: 241-248, 2007.

25. Rohwer $\mathrm{N}$ and Cramer T: Hypoxia-mediated drug resistance: Novel insights on the functional interaction of HIFs and cell death pathways. Drug Resist Updat 14: 191-201, 2011.

26. Esteban MA, Tran MG, Harten SK, Hill P, Castellanos MC, Chandra A, Raval R, O'brien TS and Maxwell PH: Regulation of E-cadherin expression by VHL and hypoxia-inducible factor. Cancer Res 66: 3567-3575, 2006.

27. Krishnamachary B, Zagzag D, Nagasawa H, Rainey K, Okuyama H, Baek JH and Semenza GL: Hypoxia-inducible factor-1-dependent repression of E-cadherin in von hippel-lindau tumor suppressor-null renal cell carcinoma mediated by TCF3, ZFHX1A and ZFHX1B. Cancer Res 66: 2725-2731, 2006.

28. Mak P, Leav I, Pursell B, Bae D, Yang X, Taglienti CA, Gouvin LM, Sharma VM and Mercurio AM: ERbeta impedes prostate cancer EMT by destabilizing HIF-1alpha and inhibiting VEGF-mediated snail nuclear localization: Implications for gleason grading. Cancer Cell 17: 319-332, 2010.

29. Nieto MA: The ins and outs of the epithelial to mesenchymal transition in health and disease. Ann Rev Cell Dev Biol 27: 347-376, 2011.

30. Yang J and Weinberg RA: Epithelial-mesenchymal transition: At the crossroads of development and tumor metastasis. Dev Cell 14: 818-829, 2008.

31. Kalluri R and Weinberg RA: The basics of epithelial-mesenchymal transition. J Clin Invest 119: 1420-1428, 2009.

32. Evans AJ, Russell RC, Roche O, Burry TN, Fish JE, Chow VW, Kim WY, Saravanan A, Maynard MA, Gervais ML, et al: VHL promotes E2 box-dependent E-cadherin transcription by HIF-mediated regulation of SIP1 and snail. Mol Cell Biol 27: 157-169, 2007.

33. Yang MH, Wu MZ, Chiou SH, Chen PM, Chang SY, Liu CJ, Teng SC and Wu KJ: Direct regulation of TWIST by HIF-1alpha promotes metastasis. Nat Cell Biol 10: 295-305, 2008.

34. Pouyssegur J, Dayan F and Mazure NM: Hypoxia signalling in cancer and approaches to enforce tumour regression. Nature 441: 437-443, 2006

35. Bernkopf DB and Williams ED: Potential role of EPB41L3 (protein 4.1B/Dal-1) as a target for treatment of advanced prostate cancer. Expert Opin Ther Targets 12: 845-853, 2008.

36. Joshi HP, Subramanian IV, Schnettler EK, Ghosh G, Rupaimoole R, Evans C, Saluja M, Jing Y, Cristina I, Roy S, Zeng Y, Shah VH, Sood AK and Ramakrishnan S: Dynamin 2 along with microRNA-199a reciprocally regulate hypoxia-inducible factors and ovarian cancer metastasis. Proc Natl Acad Sci USA 111: 5331-5336, 2014.

37. Milosevic M, Warde P, Ménard C, Chung P, Toi A, Ishkanian A, McLean M, Pintilie M, Sykes J, Gospodarowicz M, et al: Tumor hypoxia predicts biochemical failure following radiotherapy for clinically localized prostate cancer. Clin Cancer Res 18: 2108-2114, 2012

38. Cangul H, Salnikow K, Yee H, Zagzag D, Commes T and Costa M: Enhanced overexpression of an HIF-1/hypoxia-related protein in cancer cells. Environ Health Perspect 110 (Suppl 5): S783-S788, 2002.

39. Zhong H, De Marzo AM, Laughner E, Lim M, Hilton DA, Zagzag D, Buechler P, Isaacs WB, Semenza GL and Simons JW: Overexpression of hypoxia-inducible factor 1alpha in common human cancers and their metastases. Cancer Res 59: 5830-5835, 1999.

40. Ji F, Wang Y, Qiu L, Li S, Zhu J, Liang Z, Wan Y and Di W: Hypoxia inducible factor $1 \alpha$-mediated LOX expression correlates with migration and invasion in epithelial ovarian cancer. Int J Oncol 42: 1578-1588, 2013

41. Wong C, Wellman TL and Lounsbury KM: VEGF and HIF-1alpha expression are increased in advanced stages of epithelial ovarian cancer. Gynecol Oncol 91: 513-517, 2003.

42. Osada R, Horiuchi A, Kikuchi N, Yoshida J, Hayashi A, Ota M, Katsuyama Y, Melillo G and Konishi I: Expression of hypoxia-inducible factor 1alpha, hypoxia-inducible factor 2alpha and von hippel-lindau protein in epithelial ovarian neoplasms and allelic loss of von hippel-lindau gene: Nuclear expression of hypoxia-inducible factor 1alpha is an independent prognostic factor in ovarian carcinoma. Hum Pathol 38: 1310-1320, 2007.

43. Beavon IR: Regulation of E-cadherin: Does hypoxia initiate the metastatic cascade? Mol Pathol 52: 179-188, 1999. 
44. Tomita K, van Bokhoven A, van Leenders GJ, Ruijter ET, Jansen CF, Bussemakers MJ and Schalken JA: Cadherin switching in human prostate cancer progression. Cancer Res 60: 3650-3654, 2000.

45. Cano A, Pérez-Moreno MA, Rodrigo I, Locascio A, Blanco MJ, del Barrio MG, Portillo F and Nieto MA: The transcription factor snail controls epithelial-mesenchymal transitions by repressing E-cadherin expression. Nat Cell Biol 2: 76-83, 2000.

46. Yang J, Mani SA, Donaher JL, Ramaswamy S, Itzykson RA, Come C, Savagner P, Gitelman I, Richardson A and Weinberg RA: Twist, a master regulator of morphogenesis, plays an essential role in tumor metastasis. Cell 117: 927-939, 2004.

47. Polyak K and Weinberg RA: Transitions between epithelial and mesenchymal states: Acquisition of malignant and stem cell traits. Nat Rev Cancer 9: 265-273, 2009.

48. De Craene B and Berx G: Regulatory networks defining EMT during cancer initiation and progression. Nat Rev Cancer 13: 97-110, 2013.

49. Thomassin L, Werneck CC, Broekelmann TJ, Gleyzal C, Hornstra IK, Mecham RP and Sommer P: The pro-regions of lysyl oxidase and lysyl oxidase-like 1 are required for deposition onto elastic fibers. J Biol Chem 280: 42848-42855, 2005.
50. Peinado H, Del Carmen Iglesias-de la Cruz M, Olmeda D, Csiszar K, Fong KS, Vega S, Nieto MA, Cano A and Portillo F: A molecular role for lysyl oxidase-like 2 enzyme in snail regulation and tumor progression. EMBO J 24: 3446-3458, 2005.

51. Pez F, Dayan F, Durivault J, Kaniewski B, Aimond G, Le Provost GS, Deux B, Clézardin P, Sommer P, Pouysségur J and Reynaud C: The HIF-1-inducible lysyl oxidase activates HIF-1 via the Akt pathway in a positive regulation loop and synergizes with HIF-1 in promoting tumor cell growth. Cancer Res 71: 1647-1657, 2011.

52. Ye K, Hurt KJ, Wu FY, Fang M, Luo HR, Hong JJ, Blackshaw S, Ferris CD and Snyder SH: Pike. A nuclear gtpase that enhances PI3kinase activity and is regulated by protein 4.1N. Cell 103: 919-930, 2000.

53. Kisseleva MV, Cao L and Majerus PW: Phosphoinositide-specific inositol polyphosphate 5-phosphatase IV inhibits Akt/protein kinase B phosphorylation and leads to apoptotic cell death. J Biol Chem 277: 6266-6272, 2002. 